\title{
First high quality draft genome sequence of a plant growth promoting and cold active enzyme producing psychrotrophic Arthrobacter agilis strain L77
}

\author{
Ram N. Singh ${ }^{1}$, Sonam Gaba ${ }^{1}$, Ajar N. Yadav ${ }^{1}$, Prakhar Gaur ${ }^{1}$, Sneha Gulati ${ }^{1}$, Rajeev Kaushik ${ }^{1}$ and Anil K. Saxena ${ }^{1,2^{*}}$
}

\begin{abstract}
Arthrobacter agilis strain L77, is a plant growth promoting and cold active hydrolytic enzymes producing psychrotrophic bacterium, isolated from Pangong Lake, a subglacial lake in north western Himalayas, India. Genome analysis revealed metabolic versatility with genes involved in metabolism and cold shock adaptation, utilization and biosynthesis of diverse structural and storage polysaccharides such as plant based carbon polymers. The genome of Arthrobacter agilis strain L77 consists of 3,608,439 bp (3.60 Mb) of a circular chromosome. The genome comprises of 3316 protein coding genes and 74 RNA genes, 725 hypothetical proteins, 25 pseudo-genes and 1404 unique genes.
\end{abstract}

Keywords: Arthrobacter, Psychrotrophic, PGPB, Cold-active enzymes, Pangong Lake, Himalayas

Abbreviations: AFCs, Anti-freeze compounds; EPS, Exopolysaccharides

\section{Introduction}

The microorganisms from extreme environments are of particular importance in global ecology since the majority of terrestrial and aquatic ecosystems of our planet are permanently or seasonally submitted to cold temperatures. Microorganisms capable of coping with low temperatures are widespread in these natural environments where they often represent the dominant flora and they should therefore be regarded as the most successful colonizers of our planet. Members of the genus Arthrobacter $[1,2]$ are Gram-positive, show rods in exponential growth and cocci in their stationary phase, able to grow under aerobic as well as anaerobic conditions and belong to the phylum Actinobacteria [3]. Different species of Arthrobacter [1,2] have been implicated in plant growth promotion [4], production of industrially important enzymes [5, 6] and as xeroprotectant $[7,8]$. These reports suggest that species from Arthrobacter [1, 2] harbor genes for coding enzymes that can be useful in the

\footnotetext{
* Correspondence: saxena461@yahoo.com

'Division of Microbiology, ICAR-Indian Agricultural Research Institute, New Delhi 110012, India

${ }^{2}$ Present Address: ICAR-National Bureau of Agriculturally Important Microorganisms, Kushmaur, Mau 275103, Uttar Pradesh, India
}

industry, agriculture and biotechnology. Arthrobacter agilis [9] strain L77 was isolated from Pangong Lake, a subglacial lake in north western Himalayas, India and exhibit plant growth promoting attributes as well as production of hydrolytic enzymes. The culture was further characterized for production of EPS and anti-freeze compounds (AFCs). Here, we present the draft genome sequence of Arthrobacter agilis [9] strain L77 along with the description of genome properties and annotation.

\section{Organism information}

Classification and features

Arthrobacter agilis [9] strain L77 was isolated from frozen sub-glacial Pangong Lake $\left(33^{\circ} 82^{\prime} 55.59^{\prime \prime} \mathrm{N}\right.$ and $78^{\circ}$ $59^{\prime} 26.69^{\prime \prime} \mathrm{E}$ ) in north western Himalaya, India (Table 1). This psychrotrophic bacterium was isolated using standard serial dilution method on Trypticase soya agar [10] plate and has been reported to possess plant growth promoting attributes and could produce cold active enzymes and AFCs. It could solubilize phosphorus, zinc and could produce indole acetic acid and ammonia. It could produce cold active enzymes such as lipase, amylase, protease, chitinase and $\beta$-galactosidase. 
Table 1 Classification and general features of Arthrobacter agilis strain L77

\begin{tabular}{|c|c|c|c|}
\hline MIGS ID & Property & Term & Evidence code $^{a}$ \\
\hline & Classification & Domain Bacteria & TAS [12] \\
\hline & & Phylum Actinobacteria & TAS [3] \\
\hline & & Class Actinobacteria & TAS [13] \\
\hline & & Order Actinomycetales & $\operatorname{TAS}[2,14]$ \\
\hline & & Family Micrococcaceae & $\operatorname{TAS}[2,15]$ \\
\hline & & Genus Arthrobacter & TAS $[1,2]$ \\
\hline & & $\begin{array}{l}\text { Species Arthrobacter } \\
\text { agilis }\end{array}$ & TAS [9] \\
\hline & & Strain L77 & NAS \\
\hline & Gram stain & Positive & IDA \\
\hline & Cell shape & $\begin{array}{l}\text { Polymorphic: Coccus } \\
\text { to rod shaped }\end{array}$ & IDA \\
\hline & Motility & Non-motile & TAS [9] \\
\hline & Sporulation & Non-sporulating & TAS [9] \\
\hline & $\begin{array}{l}\text { Temperature } \\
\text { range }\end{array}$ & $-10^{\circ} \mathrm{C}-30^{\circ} \mathrm{C}$ & IDA \\
\hline & $\begin{array}{l}\text { Optimum } \\
\text { temperature }\end{array}$ & $15^{\circ} \mathrm{C}$ & IDA \\
\hline & $\begin{array}{l}\text { pH range; } \\
\text { Optimum }\end{array}$ & $6-9,7$ & IDA \\
\hline & Carbon source & $\begin{array}{l}\text { Yeast extract, glucose, } \\
\text { lactose, mannose }\end{array}$ & TAS [9] \\
\hline MIGS-6 & Habitat & Sub-glacial Lake & IDA \\
\hline MIGS-6.3 & Salinity & $\begin{array}{l}\text { Grown on } 5 \%> \\
\mathrm{NaCl}(\mathrm{W} / \mathrm{v})\end{array}$ & IDA \\
\hline MIGS-22 & $\begin{array}{l}\text { Oxygen } \\
\text { requirement }\end{array}$ & Aerobic & TAS [9] \\
\hline MIGS-15 & Biotic relationship & Free living & TAS [9] \\
\hline MIGS-14 & Pathogenicity & Non-pathogeneic & NAS \\
\hline MIGS-4 & $\begin{array}{l}\text { Geographic } \\
\text { location }\end{array}$ & $\begin{array}{l}\text { India, Leh Ladakh, } \\
\text { Jammu \& Kashmir }\end{array}$ & TAS [10] \\
\hline MIGS-5 & Sample collection & March 28, 2010 & IDA \\
\hline MIGS-4.1 & Latitude & $33^{\circ} 82^{\prime} 55.59^{\prime \prime} \mathrm{N}$ & NAS \\
\hline MIGS-4.2 & Longitude & $78^{\circ} 59^{\prime} 26.69^{\prime \prime} \mathrm{E}$ & NAS \\
\hline MIGS-4.4 & Altitude & $3215 \mathrm{~m}$ & NAS \\
\hline
\end{tabular}

avvidence codes - TAS Traceable Author Statement (i.e., a direct report exists in the literature), NAS Non-traceable Author Statement (i.e., not directly observed for the living, isolated sample, but based on a generally accepted property for the species, or anecdotal evidence). These evidence codes are from the Gene Ontology project [49]

Strain L77 is a bright yellow colored (Fig. 1) Grampositive, aerobic, non-motile bacterium exhibiting a rodcoccus cycle. The initial validation of bacterium was done by $16 \mathrm{~S}$ rRNA gene sequencing using the universal eubacterial primers pA (5'-AGAGTTTGATCCTGGCT CAG-3') and pH (5'-AAGGAGGTGATCCAGCCGCA3') [11]. The 16S rRNA gene sequence places Arthrobacter agilis strain L77 in the domain Bacteria [12] (Table 1), phylum Actinobacteria [3] and Class Actinobacteria [13],

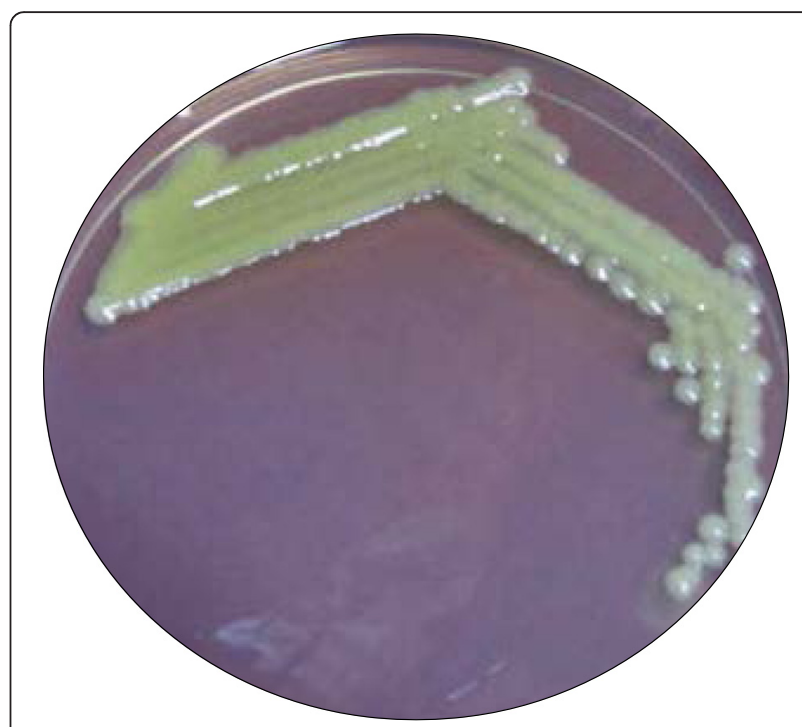

Fig. 1 Full grown yellow colored bacterial culture on Tripticase Soy Agar (TSA) medium

order Actinomycetales [2, 14] and family Micrococcaceae $[2,15]$ during homology search by BLAST [16]. Only few of the closely related species after reclassification [17] of genus Arthrobacter [1,2,] with validly published names: $A$. agilis DSM $20550^{\mathrm{T}}$ [9], A. woluwensis $1551^{\mathbf{T}}$ DSM 10495 [18], A. methylotrophus DSM $14008^{\mathrm{T}}$ [19], A. tecti LMG $22282^{\mathrm{T}}$ [20], A. parietis LMG $22281^{\mathrm{T}}$ [20], A. subterraneus $\mathrm{CH}^{\mathbf{T}}$ DSM 17585 [21], A. tumbae LMG $19501^{\mathrm{T}}$ [20], Arthrobacter oryzae KV-651 ${ }^{\mathrm{T}}$ DSM 25586 [22], Arthrobacter alkaliphilus LC6 $^{\text {T }}$ DSM 23368 [23], Arthrobacter flavus JCM $11496^{\mathbf{T}}$ [24], A. cupressi D48 $^{\mathbf{T}}$ DSM 24664 [25], A. globiformis DSM $20124^{\mathrm{T}}$ [1, 2] were selected for drawing the phylogenetic position of strain L77.

A phylogenetic tree was constructed (Fig. 2) from the $16 \mathrm{~S}$ rRNA gene sequence together with other Arthrobacter $[1,2]$ homologs using MEGA 6.0 software suite [26]. The evolutionary history was inferred by using the Maximum Likelihood method based on the Tamura-Nei model [27]. The tree with the highest log likelihood $(0.14495825)$ is shown. The percentage of trees in which the associated taxa clustered together is shown next to the branches. Initial tree(s) for the heuristic search were obtained automatically by applying Neighbor-Join and BioNJ algorithms to a matrix of pairwise distances estimated using the Maximum Composite Likelihood (MCL) approach, and then selecting the topology with superior log likelihood value. The tree is drawn to scale, with branch lengths measured in the number of substitutions per site. The analysis involved 13 nucleotide sequences. All positions containing gaps and missing data were eliminated. There were a total of 1553 positions in the final dataset. Evolutionary analyses were conducted in MEGA6.0 [26]. According to the 16S rRNA gene 


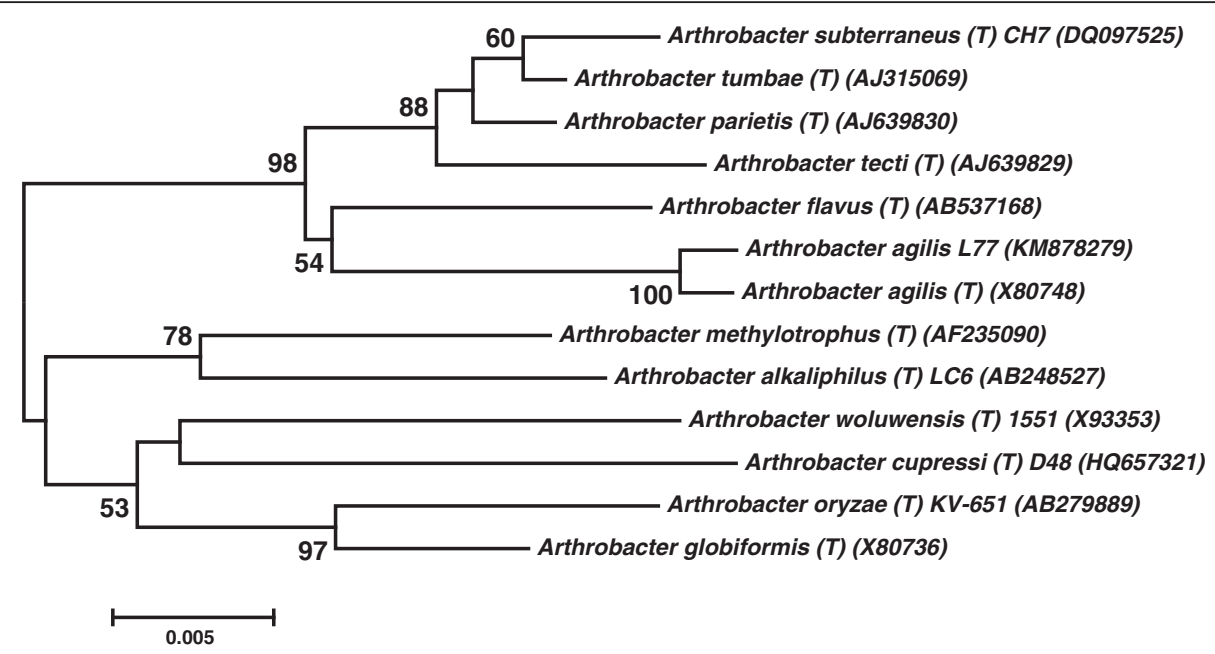

Fig. 2 Phylogenetic placements of Arthrobacter agilis strain L77 between known species of Arthrobacter genus

similarity, the nearest phylogenetic neighbors of Arthrobacter agilis strain L77 are Arthrobacter flavus JCM $11496^{\text {T }}$ [24] (AB537168) with $97.8 \%$, A. tecti LMG $22282^{\mathrm{T}}$ [20] (AJ639829) with $97.13 \%$, A parietis LMG $22281^{\mathrm{T}}$ [20] (AJ639830) with $97.41 \%$, A. subtrerraneus $\mathrm{CH} 7^{\mathbf{T}}$ DSM 17585 [21] (DQ097525) with $97.66 \%$ and $A$. tumbae LMG $19501^{\mathrm{T}}$ [20] (AJ315069) with $97.68 \%$ similarity. The 16S rRNA gene sequence also submitted to NCBI GenBank with the accession number KT804924.

\section{Extended feature descriptions}

Arthrobacter agilis strain L77, a psychrotrophic bacterium, forms bright yellow color colonies (Fig. 1) on TSA medium and could grow in a pH range of 6-9 and tolerate $5 \% \mathrm{NaCl}$. Growth studies showed that the isolate when incubated at 15 and $30{ }^{\circ} \mathrm{C}$ was in the exponential phase until $36 \mathrm{~h}$, while at $4{ }^{\circ} \mathrm{C}$, the exponential phase started after $24 \mathrm{~h}$ (Fig. 3). Freezing survival studies of Arthrobacter agilis strain L77 revealed that when the culture was initially grown at $4{ }^{\circ} \mathrm{C}$ prior to freezing at -10 and $-20^{\circ} \mathrm{C}$, it showed significantly higher freezing survival rather than culture initially grown at 15 and $30^{\circ} \mathrm{C}$ prior to freezing (Fig. 3).

Exopolysaccharide production was found to be higher at lower incubation temperatures $\left(4\right.$ or $\left.15{ }^{\circ} \mathrm{C}\right)$ in comparison to the optimal growth temperature $\left(30{ }^{\circ} \mathrm{C}\right)$ for Arthrobacter agilis (L77) (Fig. 4). EPS production by psychrophilic bacteria is one of the adaptations at low temperatures. The high polyhydroxyl content of EPS lowers the freezing point and ice nucleation temperature of

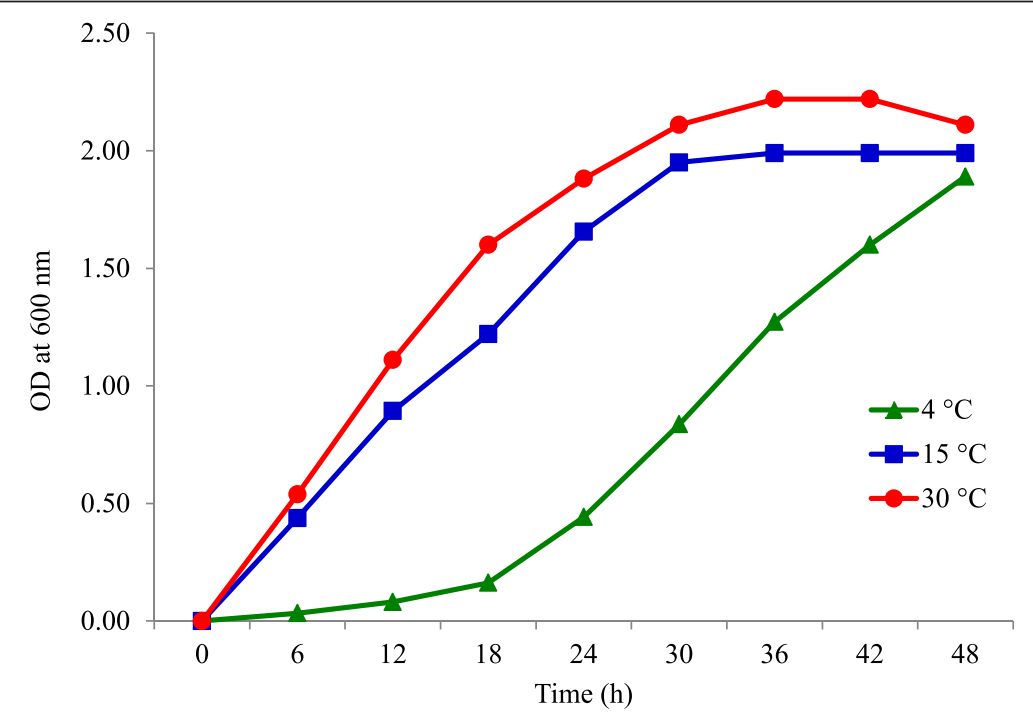

Fig. 3 Growth curves of Arthrobacter agilis strain L77 at three different temperatures 4,15 and $30{ }^{\circ} \mathrm{C}$ 


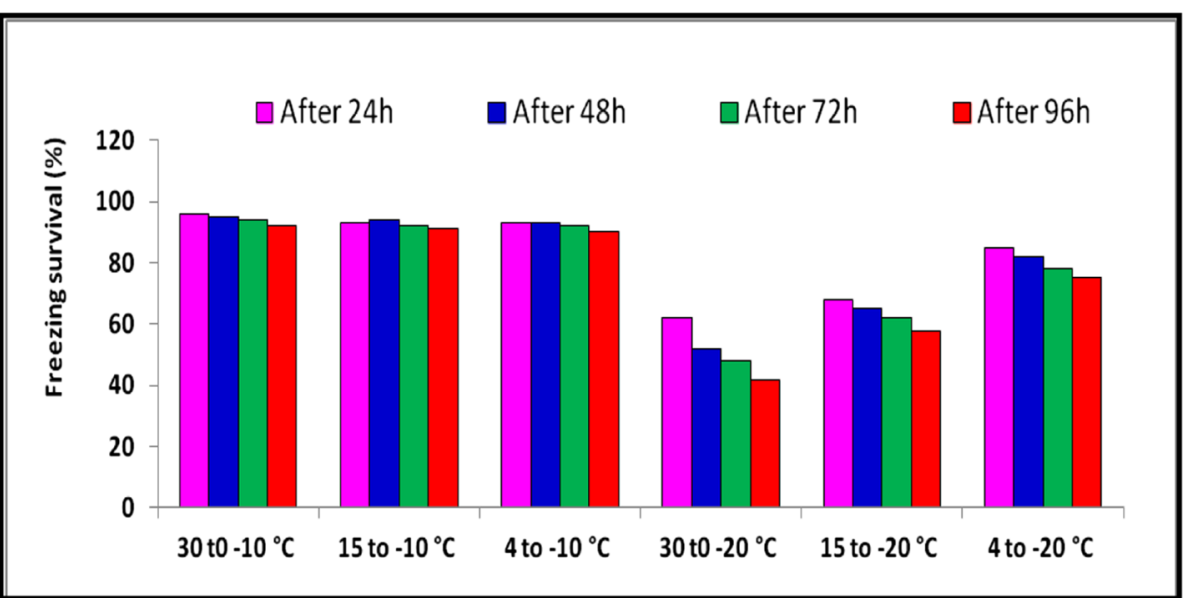

Fig. 4 The survival of Arthrobacter agilis strain L77 subjected to freezing temperature $\left(-10\right.$ and $\left.-20^{\circ} \mathrm{C}\right)$ shifted from three different temperatures 4,15 and $30^{\circ} \mathrm{C}$

water. In addition, EPS can trap water, nutrients and metal-ions and facilitate surface adhesion, cellular aggregation and biofilm formation and may also play a role in protecting extracellular enzymes against cold denaturation and autolysis [28, 29].

Remarkable variations in terms of accumulation of various organic acids, sugars, polyols and amino acids were detected through HPLC at three different incubation temperatures $\left(4,15\right.$ and $30{ }^{\circ} \mathrm{C}$ ) (Additional file 1: Table S1, Additional file 2: Table S2 and Fig. 5). Among the sugars, accumulation of mannitol and sorbitol was observed only at $4{ }^{\circ} \mathrm{C}$. The amino acids expression pattern revealed that the most prominent increase was observed in the concentrations of glycine, cysteine and arginine at $4{ }^{\circ} \mathrm{C}$ (Additional file 2: Table S2). It has been reported that the cold active enzymes and efficient growth rates are used to facilitate and maintain the

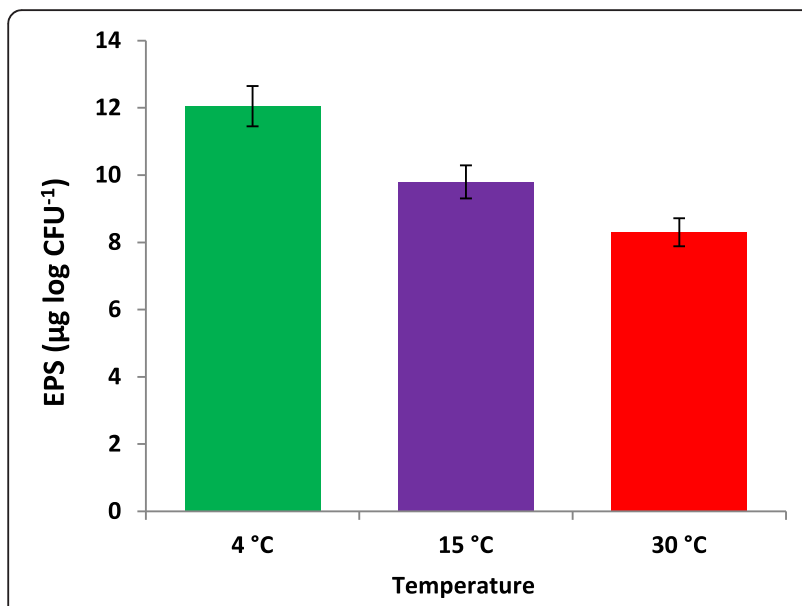

Fig. 5 EPS accumulation by Arthrobacter agilis strain $L 77$ at three different temperatures 4,15 and $30^{\circ} \mathrm{C}$ adequate metabolic fluxes at near freezing temperature for cold-adaptation [30]. The development of freezing tolerance by producing cryoprotectant compounds or adaptation of cytoplasmic enzymes to cold conditions for protecting cytoplasmic components is one of the strategy used by microbial cells to survive in freezing conditions as these molecules depress freezing point for the protection of cells [31].

Enhanced EPS production by the psychrophilic bacteria at low temperature suggests that EPS plays an important role in desiccation protection or prevention of drying of bacterial cells from freezing temperature. It can be assumed that the strain L77 follows a cold evading strategy to thrive in freezing conditions by synthesizing various cryoprotectants (sugars, polyols and amino acids). These cryoprotectants are known to depress freezing point to evade crystallization [32].

\section{Genome sequencing information}

Genome project history

This organism was selected for sequencing on the basis of its environmental and agricultural relevance to help in plant growth and ability to provide inorganic phosphate to crops at very low temperature. It also has biogeochemical importance of producing AFCs, so helpful for soil aeration. The genome project is deposited in the online genome database (NCBI-Genome). Sequencing, assembly and annotations were performed at Division of Microbiology, Indian Agricultural Research Institute (ICAR-IARI), New Delhi, India. A summary of the project information is shown in the Table 2 .

\section{Growth conditions and genomic DNA preparation}

A culture of L77 was grown in Trypticase soya broth, until they reached an $\mathrm{OD}_{(600 \mathrm{~nm})}>1.0$. The cells were 
Table 2 Genome sequencing project information for Arthrobacter agilis strain L77

\begin{tabular}{lll}
\hline MIGS ID & Property & Term \\
\hline MIGS-31 & Finishing quality & $\begin{array}{l}\text { Unfinished, improved } \\
\text { high quality draft }\end{array}$ \\
MIGS-28 & Libraries used & $\begin{array}{l}\text { Paired End } \\
\text { (insert size 250 bp) }\end{array}$ \\
MIGS-29 & Sequencing platforms & Illumina MiSeq \\
MIGS-31.2 & Fold coverage & 180× \\
MIGS-30 & Assemblers & A5 pipeline v jan-2014 \\
MIGS-32 & Gene calling method & Prodigal \\
& Locus Tag & RY94 \\
& Genbank ID & JWSU00000000.1-10.1 \\
& Genbank Date & 08-Jan-2015 \\
& Of Release & Gp0117366 \\
& GOLD ID & PRJNA270909 \\
& BIOPROJECT & L77 \\
MIGS 13 & Source Material Identifier & Bioprospecting \\
& Project relevance &
\end{tabular}

pelleted from $5 \mathrm{ml}$ culture, washed thrice with TE buffer (10 mM Tris and $1 \mathrm{mM}$ EDTA, $\mathrm{pH} 8.0$ ) and the pellet was resuspended in $750 \mu \mathrm{l}$ TE buffer. Genomic DNA was extracted from the suspended pellet using Zymo Research Fungal/Bacterial DNA MicroPrep ${ }^{\text {TM }}$ following the standard protocol prescribed by the manufacturer.

\section{Genome sequencing and assembly}

The draft genome of Arthrobacter agilis strain L77 (PRJNA270909) was generated at the Division of Microbiology, ICAR-Indian Agricultural Research Institute

Table 3 Genome Statistics for Arthrobacter agilis strain L77

\begin{tabular}{lll}
\hline Attribute & Value & \% of total \\
\hline Genome size (bp) & $3,608,439$ & 100.00 \\
DNA coding (bp) & $3,224,998$ & 89.37 \\
DNA G + C (bp) & $2,518,329$ & 69.79 \\
DNA scaffolds & 10 & 100.00 \\
Total genes & 3390 & 100.00 \\
Protein coding genes & 3316 & 97.81 \\
RNA genes & 84 & 2.18 \\
Pseudo genes & 25 & 0.73 \\
Genes in internal clusters & N/A & N/A \\
Genes with function prediction & 2591 & 78.10 \\
Genes assigned to COGs & 2122 & 63.64 \\
Genes assigned to Pfam domains & 2855 & 85.11 \\
Genes with signal peptides & 126 & 5.51 \\
Genes with transmembrane helices & 852 & 25.6 \\
CRISPR repeats & N/A & N/A \\
\hline
\end{tabular}

(ICAR-IARI), New Delhi, India using Illumina [33] technology (Table 2). For this genome, we constructed and sequenced an Illumina MiSeq shotgun library which generated 1,568,654 reads totaling $321.8 \mathrm{Mb}$ data. The raw fastq data was checked for quality using Fast QC [34]. Trimmomatic 0.32 [35] with Nextra adapter sequences was used to hard clip reads. Assembly of trimmed reads was carried out using a5 pipeline version 2014 [36] (Table 2). In terms of N50 and total number of scaffolds, the a5 pipeline [36] was found to be better than other genome assemblers. CONTIGuator [37] was used to improve the assembly draft. The final draft was identified as Arthrobacter agilis L77, using megablast with RDP $16 \mathrm{~S}$ database, release 11-1 [38]. This whole-genome project (Bioproject ID: PRJNA270909) has been registered and assembled sequence data submitted at NCBI GenBank under the accession no. JWSU00000000.1-10.1. The version described in this paper is the first version.

Table 4 Number of protein coding genes of Arthrobacter agilis strain L77 associated with general COG functional categories

\begin{tabular}{|c|c|c|c|}
\hline Code & Value & $\% \operatorname{age}^{a}$ & COG category \\
\hline$J$ & 184 & 5.54 & Translation, ribosomal structure and biogenesis \\
\hline A & 1 & 0.03 & RNA processing and modification \\
\hline K & 208 & 6.27 & Transcription \\
\hline$L$ & 109 & 3.28 & Replication recombination and repair \\
\hline B & 1 & 0.03 & Chromatin structure and dynamics \\
\hline D & 22 & 0.66 & $\begin{array}{l}\text { Cell cycle control, Cell division, chromosome } \\
\text { partitioning }\end{array}$ \\
\hline V & 49 & 1.47 & Defense mechanisms \\
\hline $\mathrm{T}$ & 113 & 3.40 & Signal transduction mechanisms \\
\hline M & 124 & 3.73 & Cell wall/membrane biogenesis \\
\hline $\mathrm{N}$ & 30 & 0.90 & Cell motility \\
\hline$U$ & 19 & 0.57 & Intracellular trafficking and secretion \\
\hline $\mathrm{O}$ & 104 & 3.13 & $\begin{array}{l}\text { Posttranslational modification, protein turnover } \\
\text { chaperones }\end{array}$ \\
\hline C & 110 & 3.31 & Energy production and conversion \\
\hline G & 213 & 6.42 & Carbohydrate transport and metabolism \\
\hline E & 200 & 6.03 & Amino acid transport and metabolism \\
\hline $\mathrm{F}$ & 71 & 2.14 & Nucleotide transport and metabolism \\
\hline $\mathrm{H}$ & 114 & 3.43 & Coenzyme transport and metabolism \\
\hline I & 88 & 2.65 & Lipid transport and metabolism \\
\hline P & 118 & 3.55 & Inorganic ion transport and metabolism \\
\hline Q & 38 & 1.14 & $\begin{array}{l}\text { Secondary metabolites biosynthesis, transport } \\
\text { and catabolism }\end{array}$ \\
\hline $\mathrm{R}$ & 204 & 6.15 & General function prediction only \\
\hline S & 166 & 5.00 & Function unknown \\
\hline - & 1030 & 31.06 & Not in COGs \\
\hline
\end{tabular}




\section{Genome annotation}

Genes were identified using Prokka 1.8 [39] based on Prodigal [40] (Table 2) as part of the Oak Ridge National Laboratory genome annotation pipeline. The predicted CDSs were further annotated on Pfam [41], and (COGs) [42]. These data sources were combined to assert a product description for each predicted protein. Noncoding genes and miscellaneous features were predicted using tRNAscan-SE [43], RNAMMer [44], Rfam [45], TMHMM [46], and signalP v4.1 [47] (Table 3).

\section{Genome properties}

The genome is $3,608,439 \mathrm{bp}$ in size, which has GC content of $69.79 \mathrm{~mol} \mathrm{\%}$ (Table 3). There are $47 \mathrm{tRNA}, 1$ tmRNA, 6 rRNA and 20 ncRNA genes. Of the 3390 predicted genes, 3316 are protein-coding genes (CDSs). Of the total CDSs, 63.64 \% represent COG functional categories and $5.51 \%$ consist of signal peptides (Table 3). The distribution of genes into COG functional categories are presented in Table 4. The genome map (Fig. 6) was visualized by $C G$ view server [48].

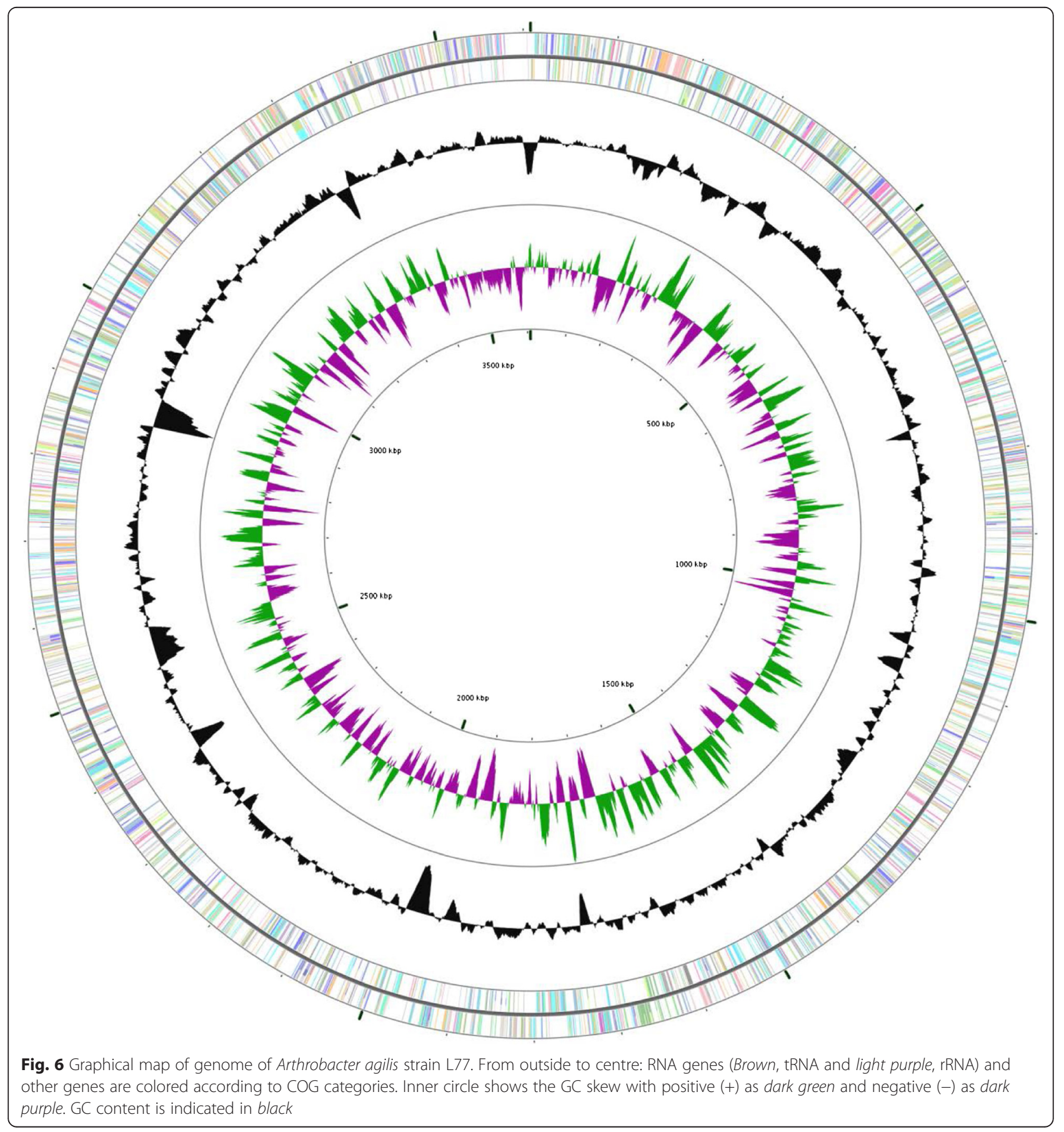


Table 5 Candidate genes coding for putative lipase, amylase, chitinase, protease, $\beta$-galactosidase, phosphate transport regulation, cold shock proteins, chaperons and heavy metal resistance activities identified in Arthrobacter agilis strain L77 draft genome

\begin{tabular}{|c|c|c|}
\hline Putative Gene & Annotation & Size (aa \\
\hline & Lipase & \\
\hline ABAGL_00531 & GDSL-like Lipase/Acylhydrolase & 262 \\
\hline ABAGL_00732 & Lipase 1 precursor & 288 \\
\hline ABAGL_00875 & GDSL-like Lipase/Acylhydrolase & 267 \\
\hline ABAGL_01161 & Lipase 1 precursor & 350 \\
\hline \multirow[t]{2}{*}{ ABAGL_03217 } & GDSL-like Lipase/Acylhydrolase & 272 \\
\hline & Amylase & \\
\hline ABAGL_00299 & Glucose-resistance amylase regulator & 338 \\
\hline ABAGL_01452 & Glucose-resistance amylase regulator & 336 \\
\hline ABAGL_01652 & Trehalose synthase/amylase TreS & 588 \\
\hline ABAGL_01737 & Alpha-amylase precursor & 905 \\
\hline ABAGL_01923 & Alpha-amylase/pullulanase & 257 \\
\hline \multirow[t]{2}{*}{ ABAGL_01950 } & Glucose-resistance amylase regulator & 327 \\
\hline & Chitinase & \\
\hline ABAGL_01394 & $\begin{array}{l}\text { putative bifunctional chitinase/lysozyme } \\
\text { precursor }\end{array}$ & 520 \\
\hline \multirow[t]{2}{*}{ ABAGL_01777 } & Chitinase & 400 \\
\hline & Protease & \\
\hline ABAGL_00100 & Putative cysteine protease YraA & 188 \\
\hline ABAGL_00190 & Flp pilus assembly protein, protease CpaA & 207 \\
\hline ABAGL_00447 & Lon protease & 364 \\
\hline ABAGL_00456 & Putative serine protease $\mathrm{HtrA}$ & 496 \\
\hline ABAGL_00667 & Serine proteasec & 401 \\
\hline ABAGL_00940 & $\begin{array}{l}\text { CAAX amino terminal protease } \\
\text { self- immunity }\end{array}$ & 268 \\
\hline ABAGL_00971 & $\begin{array}{l}\text { CAAX amino terminal protease } \\
\text { self- immunity }\end{array}$ & 247 \\
\hline ABAGL_01091 & Serine protease Do-like HtrA & 366 \\
\hline ABAGL_01213 & Rhomboid protease GluP & 291 \\
\hline ABAGL_01289 & ATP-dependent zinc metalloprotease FtsH & 689 \\
\hline ABAGL_01302 & $\begin{array}{l}\text { Putative ATP-dependent Clp protease } \\
\text { ATP-binding subunit }\end{array}$ & 835 \\
\hline ABAGL_01392 & $\begin{array}{l}\text { CAAX amino terminal protease } \\
\text { self- immunity }\end{array}$ & 266 \\
\hline ABAGL_01505 & Minor extracellular protease vpr precursor & 1059 \\
\hline ABAGL_01669 & Flp pilus assembly protein, protease CpaA & 168 \\
\hline ABAGL_01755 & $\begin{array}{l}\text { CAAX amino terminal protease } \\
\text { self- immunity }\end{array}$ & 326 \\
\hline ABAGL_02020 & Putative serine protease $\mathrm{HtrA}$ & 310 \\
\hline ABAGL_02206 & Putative metalloprotease & 303 \\
\hline ABAGL_02449 & Putative zinc metalloproteasec/MT2700 & 388 \\
\hline ABAGL_02467 & Modulator of FtsH protease HflK & 310 \\
\hline ABAGL_02638 & $\begin{array}{l}\text { ATP-dependent Clp protease ATP-binding } \\
\text { subunit ClpX }\end{array}$ & 430 \\
\hline
\end{tabular}

Table 5 Candidate genes coding for putative lipase, amylase, chitinase, protease, $\beta$-galactosidase, phosphate transport regulation, cold shock proteins, chaperons and heavy metal resistance activities identified in Arthrobacter agilis strain L77 draft genome (Continued)

\begin{tabular}{|c|c|c|}
\hline ABAGL_02639 & $\begin{array}{l}\text { ATP-dependent Clp protease proteolytic } \\
\text { subunit } 1\end{array}$ & 224 \\
\hline ABAGL_02640 & $\begin{array}{l}\text { ATP-dependent Clp protease proteolytic } \\
\text { subunit } 2\end{array}$ & 208 \\
\hline ABAGL_02862 & $\begin{array}{l}\text { ATP-dependent Clp protease adaptor } \\
\text { protein ClpS }\end{array}$ & 105 \\
\hline ABAGL_02923 & ATP-dependent zinc metalloprotease FtsH & 438 \\
\hline ABAGL_03163 & Serine protease inhibitor-like protein & 389 \\
\hline ABAGL_03211 & $\begin{array}{l}\text { CAAX amino terminal protease } \\
\text { self- immunity }\end{array}$ & 267 \\
\hline ABAGL_03271 & Metalloprotease MmpA & 447 \\
\hline ABAGL_00551 & Protease PrtS precursor & 355 \\
\hline ABAGL_00739 & Protease 2 & 734 \\
\hline ABAGL_01958 & $\begin{array}{l}\text { Protease synthase and sporulation } \\
\text { negative regulatory protein }\end{array}$ & 215 \\
\hline ABAGL_02571 & Protease PrsW & 425 \\
\hline \multirow[t]{2}{*}{ ABAGL_03295 } & Protease 3 precursor & 455 \\
\hline & $\beta$-galactosidase & \\
\hline ABAGL_00260 & $\beta$-galactosidase bgaB & 667 \\
\hline ABAGL_00292 & $\beta$-galactosidase & 687 \\
\hline \multirow[t]{2}{*}{ ABAGL_01083 } & $\beta$-galactosidase precursor & 708 \\
\hline & Phosphate Transport Regulation & \\
\hline ABAGL_01317 & $\begin{array}{l}\text { Phosphate transport system permease } \\
\text { protein PstA }\end{array}$ & 310 \\
\hline ABAGL_01318 & Phosphate import ATP-binding protein PstB & 367 \\
\hline ABAGL_01316 & $\begin{array}{l}\text { Phosphate transport system permease } \\
\text { protein PstC }\end{array}$ & 259 \\
\hline ABAGL_00191 & $\begin{array}{l}\text { Alkaline phosphatase synthesis sensor } \\
\text { protein PhoR }\end{array}$ & 544 \\
\hline ABAGL_03137 & $\begin{array}{l}\text { Alkaline phosphatase synthesis sensor } \\
\text { protein PhoR }\end{array}$ & 555 \\
\hline ABAGL_01671 & PhoH-like protein & 443 \\
\hline \multirow[t]{2}{*}{ ABAGL_02530 } & PhoH-like protein & 344 \\
\hline & Cold shock Proteins & \\
\hline \multirow[t]{2}{*}{ ABAGL_01978 } & putative cold shock protein A & 67 \\
\hline & Chaperons & \\
\hline ABAGL_01554 & $\begin{array}{l}\text { Molecular chaperone Hsp31 and } \\
\text { glyoxalase } 3\end{array}$ & 255 \\
\hline \multirow[t]{2}{*}{ ABAGL_01067 } & Copper chaperone CopZ & 74 \\
\hline & Heavy Metal Resistance & \\
\hline ABAGL_02628 & $\begin{array}{l}\text { Mercuric resistance operon regulatory } \\
\text { protein }\end{array}$ & 134 \\
\hline
\end{tabular}

\section{Insights from the genome sequence}

The isolate was successfully screened for lipase, amylase, protease, chitinase and $\beta$-galactosidase. Genome analysis 
showed two important genes pst $A$ and pst $C$ which are required for the translocation of phosphate across the membranes. Another important gene, PstB (an ADP binding protein), of the phosphate transport system is responsible for giving energy to the phosphate transport system of the organism. PhoR and PhoP were also found which are important for regulation of phosphate operon. PhoH like protein has a probable ATPase which is induced when phosphate level decreases. Genome annotation also predicted a putative cold shock protein which is supposed to play an important role in low temperature conditions. There are other proteins which shares evolutionary relationship with bacterial cold shock proteins such as Rhodanase and S1 RNA binding protein suggesting their role in low temperature conditions. In-depth analysis of the genome could give us better insight into mechanism of tolerance of this strain to low temperature. Other temperature responsive proteins were found such as molecular chaperone Hsp31 and glyoxalase 3 that influence the exposure of hydrophobic domains of proteins and stabilize the early unfolding under high temperature stress conditions to provide stability to the isolate in temperature stress.

Genes of heavy metal resistance were also found in the annotation. Mercuric resistance operon regulatory protein activates the mercury resistance operon in the presence of mercury thus protecting the bacteria from harmful sideeffects of mercury. Mercuric reductase is also present which is responsible for conversion of $\mathrm{Hg}^{2+}$ to $\mathrm{Hg}^{0} \cdot \operatorname{cop} Z$ is a copper chaperone that replaces zinc with copper and releases cop $Y$ from the DNA which is a negative regulator of $\operatorname{cop} Y Z A B$ under excess copper. Gene of nitrogen regulation, nitrogen regulatory protein P-II was found that regulates the level of nitrogen by regulating glutamine. When the ratio of glutamine to 2-ketoglutarate decreases, uridine is added on a tyrosine of P-II to form P-II-UMP which in turn deadenylates glutamine synthase resulting in its activation. Putative genes coding for these activities were identified in the genome based on annotation (Table 5).

\section{Conclusions}

The 3.6 Mb draft genome of Arthrobacter agilis strain L77 was assembled and annotated. The isolate was successfully screened for production of EPS and AFCs with potential application in biotechnology. The candidate genes coding for hydrolytic enzymes and cold shock proteins were identified in the genome. Arthrobacter agilis strain L77 will serve as a source for antifreeze proteins, functional enzymes and other bioactive molecules in future bioprospecting projects.

\section{Additional files}

Additional file 1: Table S1. Quantitative analysis of organic acid and sugars/polyols from Arthrobacter agilis strain L77 by HPLC. (DOCX $13 \mathrm{~kb}$ )
Additional file 2: Table S2. Quantitative analysis of amino acids content of Arthrobacter agilis strain L77 by HPLC. (DOCX $15 \mathrm{~kb}$ )

\section{Acknowledgments}

The authors are grateful to the National Agricultural Innovation Project (NAIP), Indian Council of Agricultural Research, Govt. of India, New Delhi and Division of Microbiology, ICAR-Indian Agricultural Research Institute (IARI), Pusa, New Delhi and for providing the financial support facilities, to undertake the investigations.

\section{Author's contributions}

RNS and SGa equally contributed to the work. RNS carried out the sample collection, participated in the strain identification, sequence alignment, assembly and annotation analysis and drafted the manuscript. SGa participated in the sequence assembly and annotation analysis. ANY and SGu carried out the bacterial isolation and performed the physiological assays. PG did the initial sequence assembly of the raw data. RK participated in sample collection and sequencing of 165 rRNA gene. AKS conceived of the study, and participated in its design, coordination and helped to finalize the manuscript. All authors read and approved the final manuscript.

\section{Competing interests}

The authors declare that they have no competing interests.

Received: 23 December 2015 Accepted: 15 August 2016

Published online: 26 August 2016

\section{References}

1. Conn H, Dimmick I. Soil bacteria similar in morphology to Mycobacterium and Corynebacterium. J Bacteriol. 1947;54(3):291.

2. Skerman V, McGowan V, Sneath P, Moore W, Moore LV. Approved lists of bacterial names. Int J Syst Bacteriol. 1980;30:225-420.

3. Garrity GM, Holt JG. The road map to the manual. Bergey's Manual ${ }^{\circledR}$ of Systematic Bacteriology. Springer New York; 2001. p. 119-66.

4. Manzanera M, Narváez-Reinaldo JJ, García-Fontana C, Vílchez JI, González-López J. Genome sequence of Arthrobacter koreensis 5J12A, a plant growth-promoting and desiccation-tolerant strain. Genome Announc. 2015;3(3):e00648-15.

5. Kallimanis A, LaButti KM, Lapidus A, Clum A, Lykidis A, Mavromatis K, et al. Complete genome sequence of Arthrobacter phenanthrenivorans type strain (Sphe3). Stand Genomic Sci. 2011;4(2):123.

6. Kiran S, Swarnkar MK, Pal M, Thakur R, Tewari R, Singh AK, et al. Complete genome sequencing of protease-producing novel Arthrobacter sp. strain IHBB 11108 using PacBio single-molecule real-time sequencing technology. Genome Announc. 2015;3(2):e00346-15.

7. Manzanera M, Santa-Cruz-Calvo L, Vílchez J, García-Fontana C, Silva-Castro G, Calvo C, et al. Genome sequence of Arthrobacter siccitolerans 4 J27, a xeroprotectant-producing desiccation-tolerant microorganism. Genome Announc. 2014;2(3):e00526-14

8. SantaCruz-Calvo L, González-López J, Manzanera M. Arthrobacter siccitolerans sp. nov., a highly desiccation-tolerant, xeroprotectant-producing strain isolated from dry soil. Int J Syst Evol Microbiol. 2013;63(Pt 11):4174-80.

9. Koch C, Schumann P, Stackebrandt E. Reclassification of Micrococcus agilis (Ali-Cohen 1889) to the genus Arthrobacter as Arthrobacter agilis comb. nov. and emendation of the genus Arthrobacter. Int J Syst Bacteriol. 1995;45(4):837-9.

10. Yadav AN, Sachan SG, Verma P, Tyagi SP, Kaushik R, Saxena AK. Culturable diversity and functional annotation of psychrotrophic bacteria from cold desert of Leh Ladakh (India). World J Microbiol Biotechnol. 2015;31(1):95-108.

11. Edwards U, Rogall T, Blöcker $H$, Emde M, Böttger EC. Isolation and direct complete nucleotide determination of entire genes. Characterization of a gene coding for 165 ribosomal RNA. Nucleic Acids Res. 1989;17(19):7843-53.

12. Woese CR, Kandler $\mathrm{O}$, Wheelis ML. Towards a natural system of organisms: proposal for the domains Archaea, Bacteria, and Eucarya. Proc Natl Acad Sci U S A. 1990:87(12):4576-9.

13. Stackebrandt E, Rainey FA, Ward-Rainey NL. Proposal for a new hierarchic classification system, Actinobacteria classis nov. Int J Syst Bacteriol. 1997; 47(2):479-91.

14. Buchanan R. Studies in the nomenclature and classification of the bacteria: II. The primary subdivisions of the schizomycetes. J Bacteriol. 1917;2(2):155.

15. Pribram E. A contributionto the classification of microörganisms. J Bacteriol. 1929;18(6):361. 
16. Altschul SF, Gish W, Miller W, Myers EW, Lipman DJ. Basic local alignment search tool. J Mol Biol. 1990;215(3):403-10.

17. Busee HJ. Review of the taxonomy of the genus Arthrobacter, emendation of the genus Arthrobacter sensu lato, proposal to reclassify selected species of the genus Arthrobacter in the novel genera Glutamicibacter gen. nov., Paeniglutamicibacter gen. nov., Pseudoglutamicibacter gen. nov., Paenarthrobacter gen. nov. and Pseudoarthrobacter gen. nov, and emended description of Arthrobacter roseus. Int J Syst Evol Microbiol. 2016;66:9-37.

18. Funke G, Hutson RA, Bernard KA, Pfyffer GE, Wauters G, Collins MD. Isolation of Arthrobacter spp. from clinical specimens and description of Arthrobacter cumminsii sp. nov. and Arthrobacter woluwensis sp. nov. J Clin Microbiol. 1996;34(10):2356-63.

19. Borodina E, Kelly DP, Schumann P, Rainey FA, Ward-Rainey NL, Wood AP. Enzymes of dimethylsulfone metabolism and the phylogenetic characterization of the facultative methylotrophs Arthrobacter sulfonivorans sp. nov., Arthrobacter methylotrophus sp. nov., and Hyphomicrobium sulfonivorans sp. nov. Arch Microbiol. 2002;177(2):173-83.

20. Heyrman J, Verbeeren J, Schumann P, Swings J, De Vos P. Six novel Arthrobacter species isolated from deteriorated mural paintings. Int I Syst Evol Microbiol. 2005;55(4):1457-64.

21. Chang H, Bae J, Nam Y, Kwon H, Park JR, Shin K, et al. Arthrobacter subterraneus sp. nov., isolated from deep subsurface water of the South Coast of Korea. J Microbiol Biotechnol. 2007;17(11):1875.

22. Kageyama A, Morisaki K, Ōmura S, Takahashi Y. Arthrobacter oryzae sp. nov. and Arthrobacter humicola sp. nov. Int J Syst Evol Microbiol. 2008;58(1):53-6.

23. Ding L, Hirose T, Yokota A. Four novel Arthrobacter species isolated from filtration substrate. Int J Syst Evol Microbiol. 2009:59(4):856-62.

24. Reddy G, Aggarwal R, Matsumoto G, Shivaji S. Arthrobacter flavus sp. nov., a psychrophilic bacterium isolated from a pond in McMurdo Dry Valley, Antarctica. Int J Syst Evol Microbiol. 2000;50(4):1553-61.

25. Zhang J, Ma Y, Yu H. Arthrobacter cupressi sp. nov., a novel actinomycete isolated from the rhizosphere soil of Cupressus sempervirens. Int J Syst Evol Microbiol. 2012. doi:10.1099/ijs.0.036889-0.

26. Tamura K, Stecher G, Peterson D, Filipski A, Kumar S. MEGA6: molecular evolutionary genetics analysis version 6.0. Mol Biol Evol. 2013;30(12):2725-9.

27. Tamura K, Nei M. Estimation of the number of nucleotide substitutions in the control region of mitochondrial DNA in humans and chimpanzees. Mol Biol Evol. 1993;10(3):512-26.

28. Nichols CM, Guezennec J, Bowman J. Bacterial exopolysaccharides from extreme marine environments with special consideration of the southern ocean, sea ice, and deep-sea hydrothermal vents: a review. Mar Biotechnol. 2005;7(4):253-71.

29. Poli A, Anzelmo G, Nicolaus B. Bacterial exopolysaccharides from extreme marine habitats: production, characterization and biological activities. Marine Drugs. 2010;8(6):1779-802.

30. Shivaji S, Prakash JS. How do bacteria sense and respond to low temperature? Arch Microbiol. 2010;192(2):85-95.

31. Yamashita $Y$, Nakamura N, Omiya K, Nishikawa J, Kawahara H, Obata H. Identification of an antifreeze lipoprotein from Moraxella sp. of Antarctic origin. Biosci Biotech Biochem. 2002;66(2):239-47.

32. Chattopadhyay M. Cold-adaptation of Antarctic microorganisms-possible involvement of viable but nonculturable state. Polar Biol. 2000;23(3):223-4.

33. Bennett EA, Massilani D, Lizzo G, Daligault J, Geigl E-M, Grange T. Library construction for ancient genomics: Single strand or double strand? BioTechn. 2014;56(6):289

34. Andrews S. FastQC: a quality control tool for high throughput data. Reference Source. 2010.

35. Bolger AM, Lohse M, Usadel B. Trimmomatic: a flexible trimmer for Illumina sequence data. Bioinformatics. 2014. doi:10.1093/bioinformatics/btu170.

36. Coil D, Jospin G, Darling AE. A5-miseq: an updated pipeline to assemble microbial genomes from Illumina MiSeq data. Bioinformatics. 2014. doi:10.1093/bioinformatics/btu661.

37. Galardini M, Biondi EG, Bazzicalupo M, Mengoni A. CONTIGuator: a bacterial genomes finishing tool for structural insights on draft genomes. Source Code Biol Med. 2011;6:11.

38. Cole JR, Wang Q, Cardenas E, Fish J, Chai B, Farris RJ, et al. The Ribosomal Database Project: improved alignments and new tools for rRNA analysis. Nucleic Acids Res. 2009;37 suppl 1:D141-5.

39. Seemann T. Prokka: rapid prokaryotic genome annotation. Bioinformatics. 2014. doi:10.1093/bioinformatics/btu153.
40. Hyatt D, Chen G-L, LoCascio PF, Land ML, Larimer FW, Hauser LJ. Prodigal: prokaryotic gene recognition and translation initiation site identification. BMC Bioinformatics. 2010;11(1):119.

41. Bateman A, Coin L, Durbin R, Finn RD, Hollich V, Griffiths-Jones S, et al. The Pfam protein families database. Nucleic Acids Res. 2004;32 suppl 1:D138-41.

42. Tatusov RL, Koonin EV, Lipman DJ. A genomic perspective on protein families. Science. 1997;278(5338):631-7.

43. Lowe TM, Eddy SR. tRNAscan-SE: a program for improved detection of transfer RNA genes in genomic sequence. Nucleic Acids Res. 1997;25(5):0955-64

44. Lagesen K, Hallin P, Rødland EA, Stærfeldt H-H, Rognes T, Ussery DW. RNAmmer: consistent and rapid annotation of ribosomal RNA genes. Nucleic Acids Res. 2007:35(9):3100-8.

45. Griffiths-Jones S, Bateman A, Marshall M, Khanna A, Eddy SR. Rfam: an RNA family database. Nucleic Acids Res. 2003;31(1):439-41.

46. Krogh A, Larsson B, Von Heijne G, Sonnhammer EL. Predicting transmembrane protein topology with a hidden Markov model: application to complete genomes. J Mol Biol. 2001;305(3):567-80.

47. Bendtsen JD, Nielsen H, von Heijne G, Brunak S. Improved prediction of signal peptides: SignalP 3.0. J Mol Biol. 2004;340(4):783-95.

48. Grant JR, Stothard P. The CGView server: a comparative genomics tool for circular genomes. Nucleic Acids Res. 2008;36 suppl 2:W181-4.

49 Ashburner M, Ball CA, Blake JA, Botstein D, Butler H, Cherry JM, Davis AP, Dolinski K, Dwight SS, Eppig JT, Harris MA, Hill DP, Traver LIKasarskis A, Lewis S, Matese JC, Richardson JE, Ringwald M, Rubin GM, Sherlock G. Gene Ontology: tool for the unification of biology. Nat Genet. 2000; 25(1):25-29.

\section{Submit your next manuscript to BioMed Central and we will help you at every step:}

- We accept pre-submission inquiries

- Our selector tool helps you to find the most relevant journal

- We provide round the clock customer support

- Convenient online submission

- Thorough peer review

- Inclusion in PubMed and all major indexing services

- Maximum visibility for your research

Submit your manuscript at www.biomedcentral.com/submit
C Biomed Central 